\title{
Environmental Parameters Controlling Mlerobial Activities in Terrestrial Subsurface Environments
}

\author{
Thomas L. Kieft \\ Department of Biology \\ New Mexico Institute of Mining and Technology \\ Socorro, NM 87801
}

TECHNICAL COMPLETION REPORT

\author{
U. S. Department of Energy \\ Office of Energy Research \\ Subsurface Science Program \\ Deep Microbiology Subprogram
}

Grant Number DE-FG04-88EF60711

\section{DISCLAIMER}

This report was prepared as an account of work sponsored by an agency of the United States Government. Neither the United States Govesnment nor any agency thereof, nor any of their employees, makes any warranty, express or implied, or assumes any legal liability or responsibility for the accuracy, completenc5s, or usefulness of any information, apparatus, product, or process disclosed, or represents that its use would not infringe privately owned rights. Reference herein to any specific commercial product, process, or service by trade name, trademark, manufacturet, or otherwise does not necessarily constitute or imply its endorsement, recommendation. or favoring by the United States Government or any agency thereof. The views and opinions of authors expressed herein do not necessarily state or reflect those of the United Stutes Government or any agency thereof. 


\title{
Environmental Parameters Controlling Mlcrobial Activities in Terrestrial Subsurface Environments
}

\author{
Thomas L. Kieft \\ Department of Biology \\ New Mexico Institute of Mining and Technology \\ Socorro, NM 87801
}

This project was begun in July 1988 as part of Phase I of the Deep Microbiology Subprogram. At this time, the Subprogram was preparing for sampling near the Savannah River Site (SRS) from what was being termed the "Investigator's Hole." This was the fourth hole (later designated C10) drilled for sampling in the coastal plain sediments at a site near the SRS. Since there was a possibility of sampling from the saline Triassic basin in the deeper regions in this fourth hole, there was particular interest in quantifying halotolerant microorganisms from these samples and in determining the responses of subsurface microbes to a range of salt concentrations. Further interest in the salt tolerances of microbes from these coastal siadiments arose from the fact that all of these sediments were deposited under marine conditions. It was also anticipated that samples would be available from the shallow unsaturated (vadose) zone at this site, so there was interest in quantifying microbial responses to matric water potential as well as solute water potential.

The initial objectives of this research project were to:

1. Characterize microbial communities in a saline aquifer

2. Determine the potential for microbial metabolism of selected organic compounds in saline aquilers

3. Characterize microbial communities in unsaturated subsurface materials (vadose zones).

4. Determine the potential for microbial metabolism of selected organic compounds in unsaturated subsurface materials (vadose zones).

Samples were collected from the borehole during a period extending from August to October 1988. A total of nine samples were express shipped to New Mexico Tech for analyses. These were all saturated zone samples from six different geological formations (Table 1). Water contents and water potentials were measured at the time of sample arrival (Table 1).

\section{Major findings and accomplishments:}

1. The water contents and water potentials were measured for each of the samples. Since these were all saturated samples, it was expected that the matric water potentials would be near zero. Since none of the samples came from a iruly saline aquifer, it was also expected that the solute water potentials would be insignificant. The deepest sample, however, did show evidence of slightly elevated solute concentrations. Two of the samples, 10 and 14 , had water potentials of -2.70 and 2.07, respectively, when measured at the tirne of arival. Since these are unlikely 
Table 1 Water potential and water content of SRS corehole C-10 samples received at Now Mexico Tech.

\begin{tabular}{rrlll} 
Sample No. & Depth $(\mathrm{m})$ & Formation & $\%$ Moisture & Water potential (MPa) \\
\hline & & & & \\
\hline & 10 & Tobacco Road & 23.7 & -0.163 \\
5 & 70 & McBean & 29.3 & -0.052 \\
6 & 119 & McBean & 20.3 & -0.138 \\
8 & 194 & Ellenton & 34.7 & -0.148 \\
9 & 212 & Ellenton & 27.4 & -0.044 \\
10 & 238 & Pee Dee & 15.1 & -2.70 \\
14 & 324 & Middendor & 32.0 & -2.07 \\
15 & 378 & Middendorf & 12.7 & -0.176 \\
20 & 436 & Cape Fear & 17.8 & -0.659 \\
& & &
\end{tabular}

water potential values for saturated, non-saline aquifers, it appears that the sample handling altered the water potentials. Handling in the glove bag in a dry $\mathrm{N}_{2}$ atmosphere may have caused the apparent desiccation. This drying of the sample could have a detrimental effect on the viability/culturability of microorganisms in these samples. Future sampling efforts should take this into consideration.

2. The numbers and activities of microorganisms were quantified in the 9 samples. This was, in part, a contribution to the overall effort of microbiologists within the program to characterize the samples. It was also part of the specific task of this project to characterize microorganisms with respect to water potential. The microbiological assays performed included standard plate counts, measurement of microbial respiration rates, measurement of microbial biomass, ATP measurements, and adenylate energy charge measurements. The results of this microbiological characterization have been published (Kieft and Rosacker, 1991; Kieft et al, 1991).

3. The ratios of respiration rates to biomass carbon contents (metabolic quotient) and the ratios of biomass carton to total organic carbon in the samples were suggestive of relatively inactive microbial communities.

4. The adenyiate energy charge data also indicate that the microbes in these samples were relatively inactive. Five out of eight samples had adenylate energy charge values below 0.5 , indicating that many of the cells present were dead or dying. 
5. Respiration rates in the samples were correlated with adenylate energy charge $(\mathbb{R}<$ 0.01).

6. Matric and solute water potentials were each shown to have an inhibitory effect on the ability of microorganisms in the SRS samples to metabolize exogenously supplied ${ }^{14} \mathrm{C}$-labeled organic substrates (Figs. 1 and 2). Matric water potentials inhibited glucose and acetate mineralization at matric water potentials less than approximately $-0.1 \mathrm{MPa}$ (Fig. 1). At this water potential, inhibition is caused not by the direct effects of desiccation, but rather by the inaccessibility of nutrients. The water films at this matric water potential are so thin that solute diffusion, solute advection, and microbial mobility are greatly reduced. This situation is essentially identical to that which occurs in unsaturated subsurface material. Solute water potentials less than approximately $-0.5 \mathrm{MPa}$ (imposed by $\mathrm{NaCl}$ ) also greatly reduced rates of microbially mediated organic substrate mineralization (Fig. 2). This indicates that the microbes present in these samples are not marine. Marine microorganisms show the greatest activity at approximately $0.6 \mathrm{M} \mathrm{NaCl}(-2.8 \mathrm{MPa}$ solute water potential). This finding has implications for the origins of microorganisms in these coastal plain sediments. Although the sediments were deposited under marine conditions, the present salt concentrations are relatively low and the microbes do not have the characteristics of marine bacteria.

7. A heterotrophic thiosulfate-oxidizing bacterium was isolated from the Middendort formation (sample 15). This was identified as Pseudomonas testosteroni. Although thiosulfate oxidation is not unusual among heterotrophic bacteria, the selective advantage of this trait has not been determined. Our experiments with this isolate suggest that thiosulfate can serve as an external energy source during starvation survival. Since thiosulfate is present in the porewater of the Middendorf formation, thiosulfate-enhanced starvation survival may confer selective advantage in this subsurface environment. We presented these findings at the First international Symposium on the Microbiology of the Deep Subsurface and in the Proceedings from that meeting.

8. We have also isolated an Acinetobacter sp. from the Middendorf formation (sample 14). Although initial standard plate counts from this sample showed no growth, bacteria of this strain could be cultured in relatively high numbers after the sample had been stored in the refrigerator for 3 weeks. This was an early example of the increase in numbers of culturable microorganisms which is frequently observed after storage of subsurface samples. We are currently investigating this phenomenon in collaboration with Fred Brockman and Jim Fredrickson at Pacific Northwest Laboratories.

9. We have tested both the Pseudomonas testosteroni and the Acinetobacier sp. from the Middendort formation for their abilities to survive starvation under various matric water potential conditions. Both are starvation tolerant, but only the Acinetobacter can remain viable for extended periods under dry conditions (Fig. 3). Starvation/ desiccation survival data on these two subsurface isolates were presented at the First 

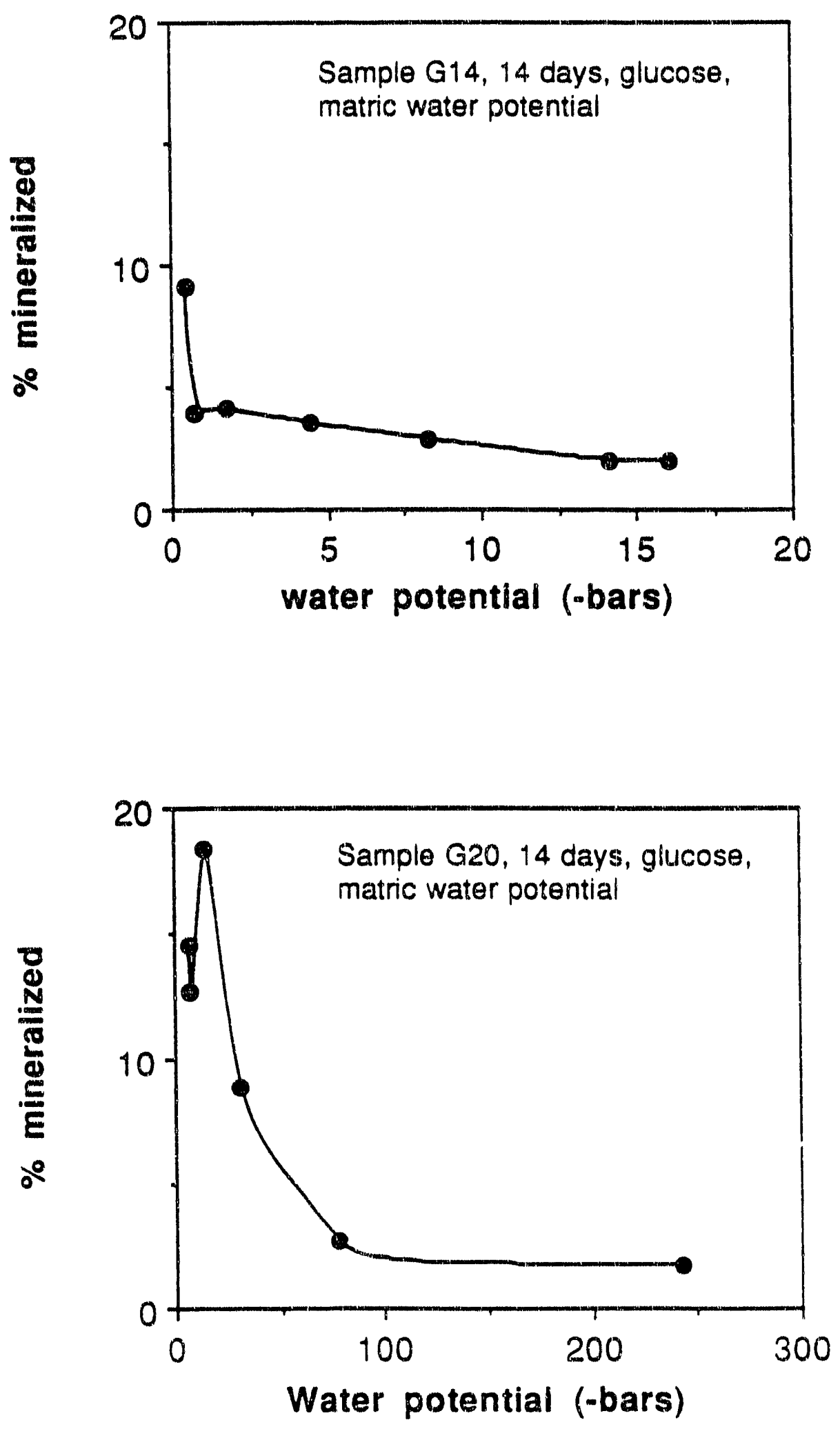

Fig. 1. Effects of matric water potential on mineralization of ${ }^{14} \mathrm{C}$-labeled glucose in Savannah River Site $\mathrm{C} 10$ borehole samples. 

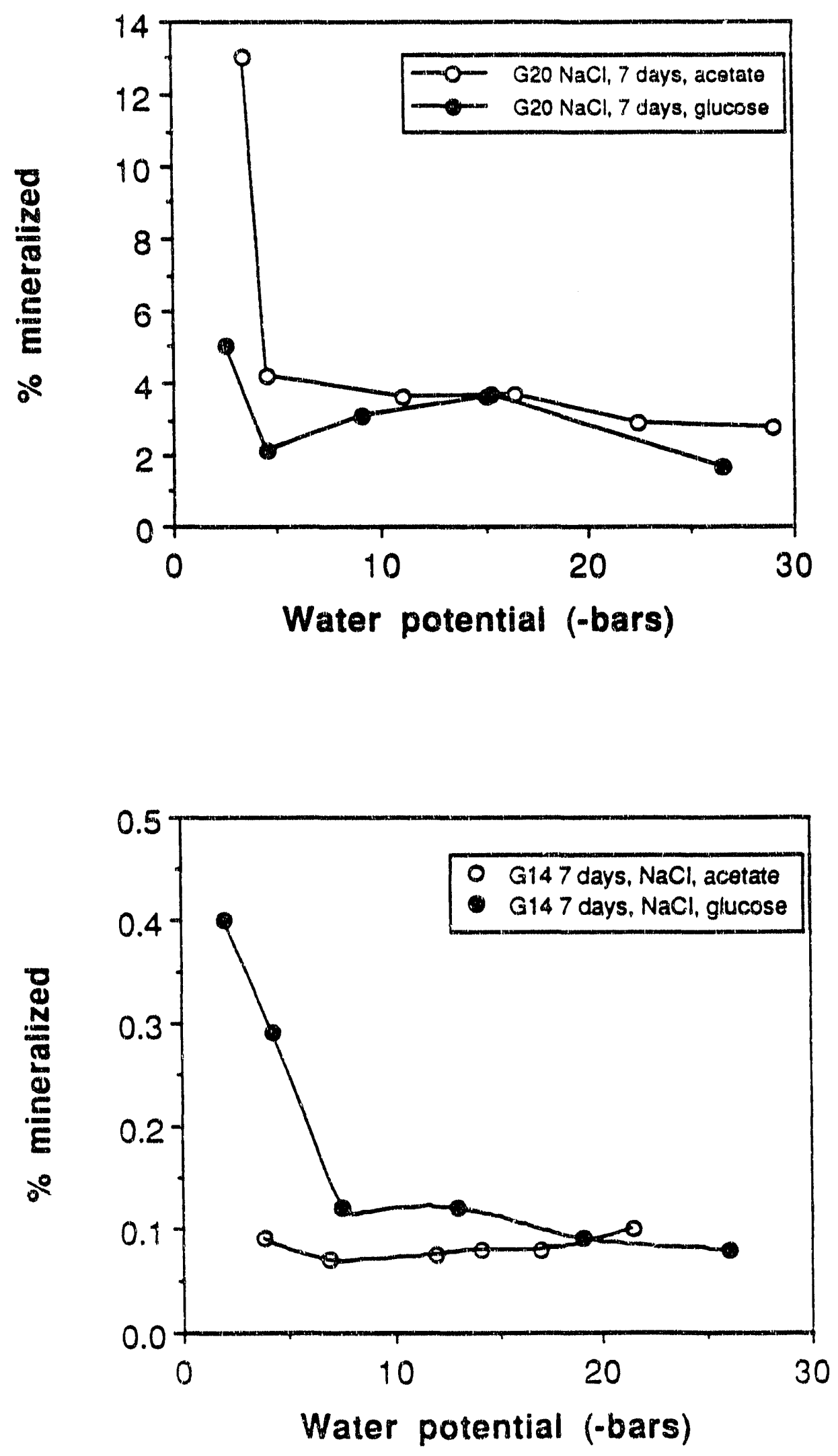

Fig. 2. Effects of solute water potential (imposed by $\mathrm{NaCl}$ ) on mineralization of ${ }^{14} \mathrm{C}$ labeled organic substrates in Savannah River Site $\mathrm{C} 10$ borehole samples. 
A

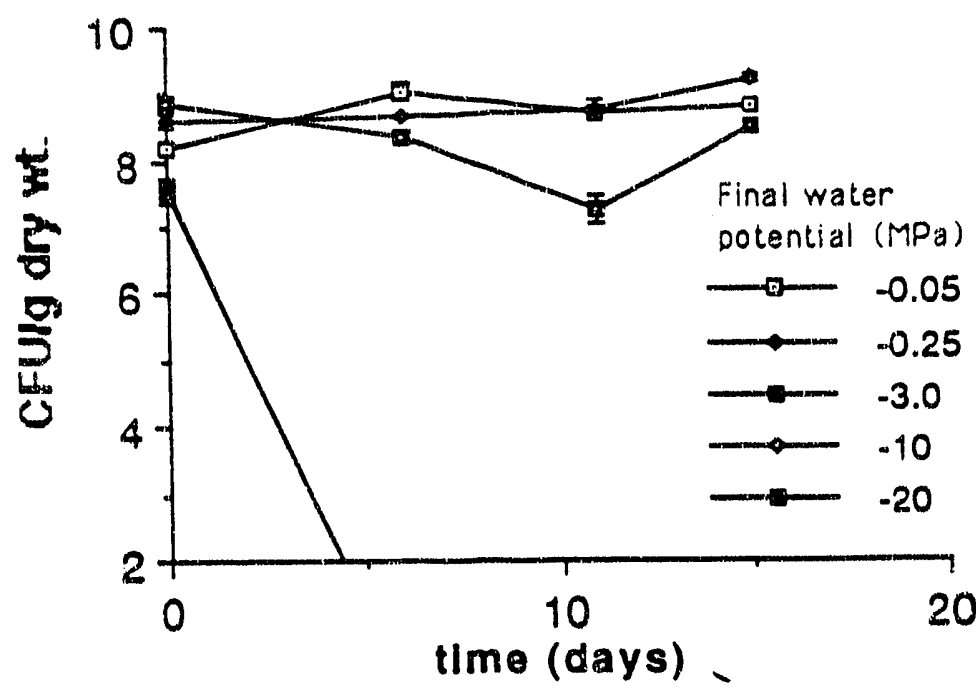

B

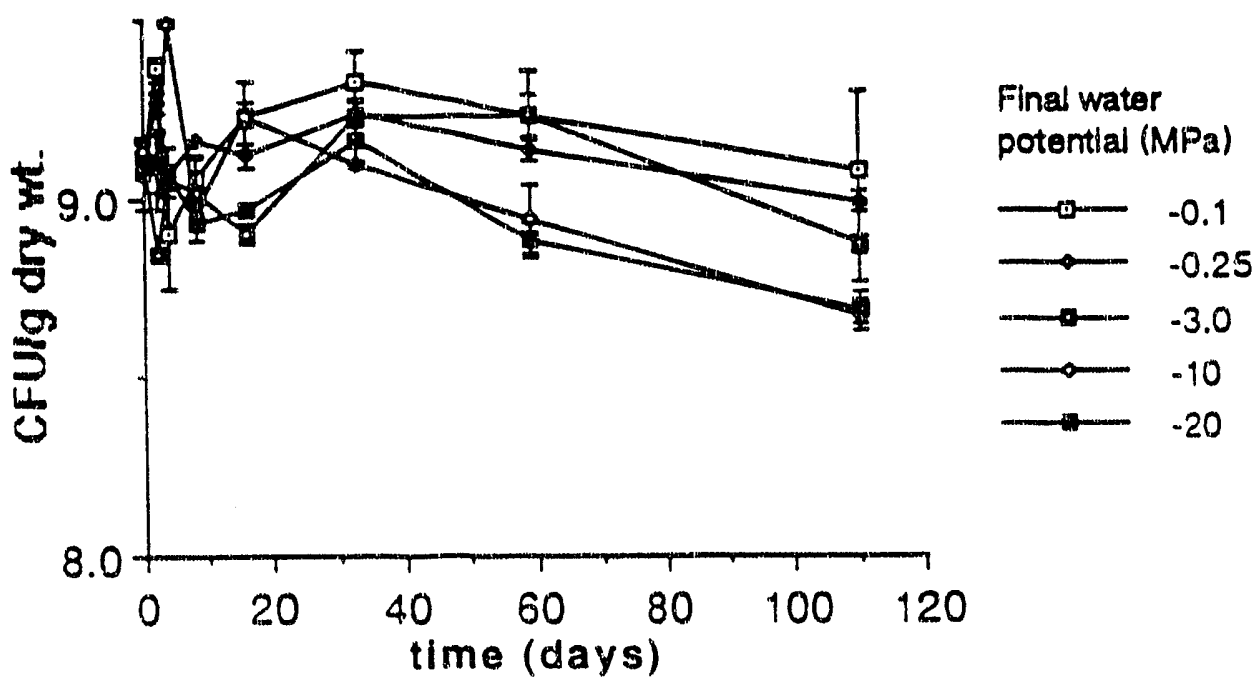

Fig. 3. Starvation-survival at different matric water potentials of two isolates from the Middendorf formation at the Savannah River Site $\mathrm{C} 10$ borehole. A. Pseudomonas testosteroni and $\mathrm{B}$. Acinetobactersp. 
International Symposium on the Microbiology of the Deep Subsurface and in the Proceedings from that meeting. We are continuing this investigation of starvation/desiccation tolerance in our current DOE project using subsurface isolates from arid western sites. We are also continuing physiological testing of our Acinetobacter isolate to determine physiological traits which enable desiccation tolerance. Part of this work is being done in collaboration with David White and David Ringelberg at the University of Tennessee.

10. During the closing weeks of this project, work was begun to analyze buried paleosol samples from the Hanford site. This project has been carried out in collaboration with Fred Brockman at Pacific Northwest Laboratories and it is continuing as part of my currently funded DOE project. This work with paleosols has so far resulted in three national meeting presentations and one paper in press (Brockman et al. 1992).

Unfortunately, not all of the objectives outlined in the original proposal were met. This can be explained by the types of samples which were made available. Because the Triassic basin was not encountered in the drilling, saline aquifer material could not be characterized. Samples from the shallow unsaturated zone were not available. However, the saturated zone samples which were made available were thoroughly characterized in terms of microbial responses to water potential. This provides important baseline data for comparison with Transition Phase data on water relations of microbes in subsurface samples at arid western sites. Work during this period was also extremely important for developing methods in determining microbial responses to water potential. Moreover, microbiological characterization of these nine samples from the Savannah River Site has provided valuable information regarding the physiological state of subsurface microorganisms and their potential for long-term survival under subsurface conditions.

\section{Publications:}

Kieft, T. L. and L. L. Rosacker. 1991. Application of adenylate- and respiration-based soil microbiological assays to deep subsurface terrestrial sediments. Soil Biology and Biochemistry 23:563-568.

Kieft, T. L., L. L. Rosacker, D. Willcox, and A. J. Franklin. 1991. Water potential and starvation stress in deep subsurface microorganisms. In: Proceedings of the First International Symposium on Microbiology of the Deep Subsurface. Orlando, FL, January 16, 1990. (C. B. Fliermans and T. C. Hazen, Eds.) pp. 4-99 to 4-12. WSRC Information Services, Aiken SC.

Kieft, T. L. and A. J. Franklin. Heterotrophic thiosulfate oxidation in a Pseudomonas $\mathrm{sp}$. isolated from a deep subsurface sediment. (In preparation).

Brockman, F. J., T. L. Kieft, J. K. Fredrickson, B. N. Bjornstad, S. W. Li, W. Spangenberg, and P. E. Long. 1992. Microbiology of vadose zone paleosols in south-central Washington. Microbial Ecology (In Press). 
Presentations at meetings:

Kieft, T. L., Water potential and starvation stress in deep subsurface microorganisms. First International Symposium on Microbiology of the Deep Subsurface. Orlando, FL, January 16, 1990.

Bjornstad, B. N., F. Brockman, T. L. Kieft, and P. E. Long. Subsurface microbial distribution in the vadose zone, Hanford site, south-central Washington. American Geophysical Union Annual Fall Meeting, December 4, 1990.

Kieft, T. L., L. L. Rosacker, and K. Crist. Numbers and activities of microorganisms in the vadose zones of arid and semiarid sites. American Society for Microbiology Annual Meeting. May 6, 1991.

Brockman, F. J., T. L. Kieft, J. K. Fredrickson, W. Spangenberg, S. W. Li, and D. J. Workmail. Microbiological characterization of vadose zone sediments at the Hanford Site, south-central Washington state. American Society for Microbiology Annual Meeting. May 6, 1991. 

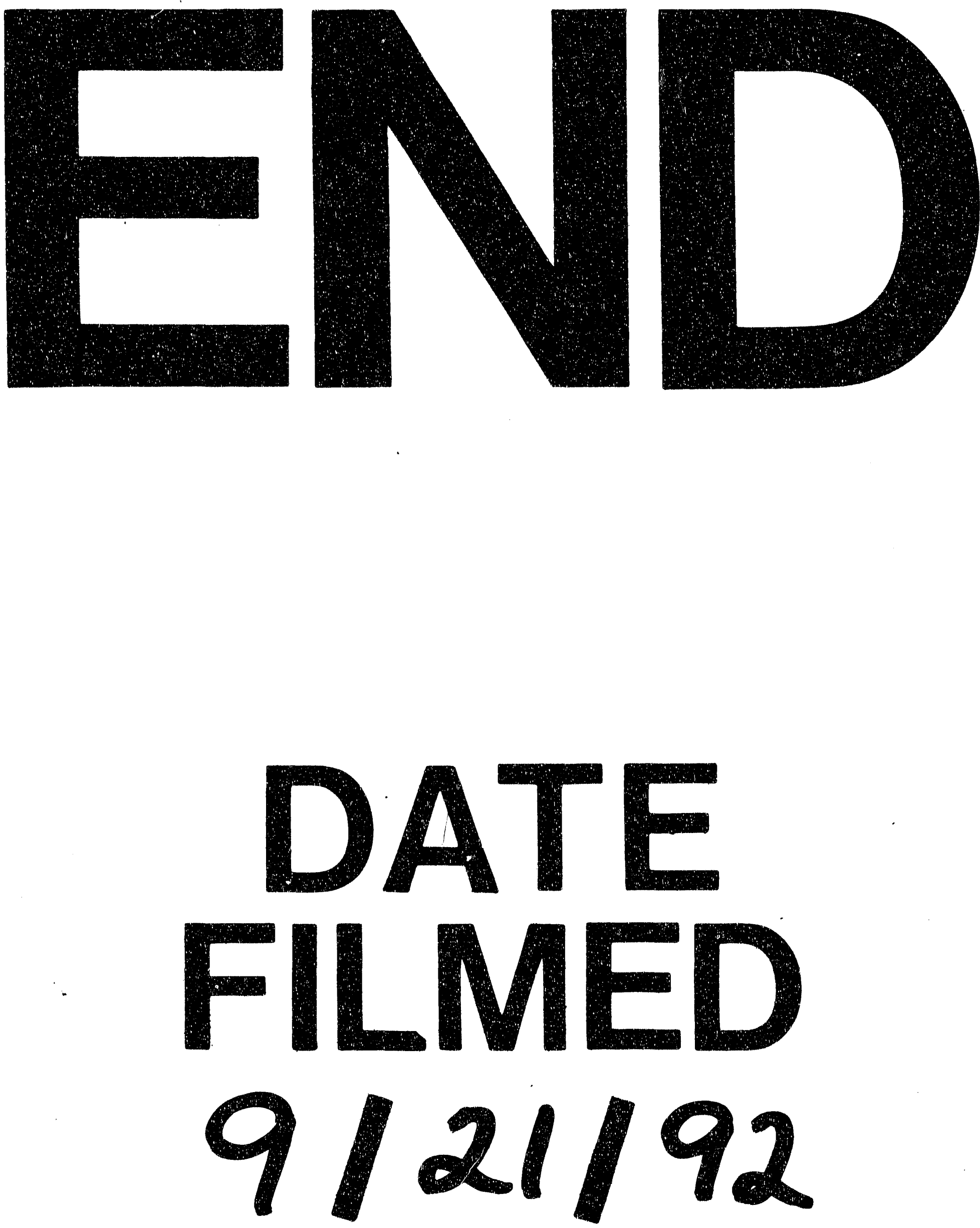
